\title{
Temporal and Spatial Analysis of Grapevine Leafroll-Associated Virus 3 in Pinot Noir Grapevines in Australia
}

\author{
Nuredin Habili, Senior Research Scientist, Cooperative Research Centre for Viticulture and CSIRO Division of \\ Horticulture, GPO Box 350 Adelaide, South Australia 5001, and Forrest W. Nutter, Jr., Associate Professor, De- \\ partment of Plant Pathology, Iowa State University, Ames 50011
}

\begin{abstract}
Habili, N., and Nutter, F. W., Jr. 1997. Temporal and spatial analysis of grapevine leafroll-associated virus 3 in Pinot Noir grapevines in Australia. Plant Dis. 81:625-628.

An epidemic of grapevine leafroll disease (GLD), caused by grapevine leafroll-associated virus 3 (GLRaV-3), was monitored over an 11-year period in Nuriootpa, South Australia. Inoculum originated from infected budwood, and initial GLD incidence at the time of transplanting in 1986 was $23.1 \%$. Infected vines were planted in a random spatial pattern. Change in disease incidence was not observed until 8 years after planting, when disease incidence increased to $27.9 \%$. Disease incidence increased to $51.9 \%$ by 1996 . Disease progress and rate curves $(d y / d t$ versus time) indicated that the logistic $\left(R^{2}=96.2\right)$ and Gompertz $\left(R^{2}=96.3\right)$ growth models would best describe disease progress. However, the logistic model, which has a simpler data transformation with fewer model assumptions, was chosen for the purpose of comparing this epidemic (South Australia) with a GLRaV-3 epidemic in Cabernet Sauvignon grapevines in New Zealand. The logistic rate of GLD spread with respect to time was 0.35 logit/year in South Australia and was nearly three times faster (1.19 logits/year) for GLRaV-3 spread in New Zealand. Ordinary runs analyses indicated that the arrangement of infected vines within rows in South Australia was random up to 8 years after transplanting but subsequently became highly aggregated. Thus, GLD-infected plants are contributing to new infections (i.e., there is evidence for plant-to-plant spread), and a biotic vector with a steep dispersal gradient from each point source is likely to be involved.
\end{abstract}

Grapevine leafroll disease (GLD) is a graft-transmissible and economically important disease of grapevines (Vitis spp.) in many parts of the world (10). This disease is caused by seven serologically distinct clostero-like viruses that have been isolated from GLD-infected grapevines $(2,4,5,9)$. Although these viruses do not kill vines, yield losses due to poor fruit set have been estimated to be 20 to $40 \%$ in infected vines $(10,21)$. In addition, GLD affects quality by delaying maturity and decreasing sugar content and color in red cultivars $(10,12)$. The viruses causing symptoms of GLD are commonly associated with the phloem of diseased grapevines, and it has been hypothesized previously that GLD is spread only by infected propagating material and that plant-toplant spread within vineyards does not occur (10). Since 1989, however, GLD

Corresponding author: Forrest W. Nutter, Jr. E-mail: fwn@iastate.edu

This work was partly supported by the South Australian Research and Development Institute while the second author was on sabbatical leave and by the Iowa Agriculture and Home Economics Experiment Station, Ames. Journal Paper No. J16969 , Project 3116.

Accepted for publication 4 March 1997.

Publication no. D-1997-0423-05R

(C) 1997 The American Phytopathological Society spread has been observed in vineyards $(7,9,11,18)$. Two grape leafroll viruses (GLRaV-3 and GLRaV-2) are reported to spread in the field $(1,2,8,17-19)$. Grapevine leafroll-associated virus 3 (GLRaV-3) was recently found to be vectored by mealybugs (Planococcus ficus Signoret) in South Africa (7), the United States (8), Sicily (17), and Israel (18), and by the scale insect Pulvinaria vitis L. in Italy (1).

The etiology and epidemiology of grapevine leafroll closterovirus diseases are not well understood, and quantitative epidemiological information concerning the spatial and temporal dynamics of GLRaV-3 in grapevines has not been published. Recently, the natural spread of GLRaV-3 in a Pinot Noir vineyard in Australia was reported (9), but at the time this paper was published, there were insufficient quantitative data to analyze the temporal and spatial spread of this virus statistically. Jordan (11) also reported plant-toplant spread of GLRaV-3 in Cabernet Sauvignon grapevines in New Zealand; however, temporal and spatial analyses were not reported. Additional quantitative information is needed to support the existence of plant-to-plant spread of GLRaV-3 in grapevines as proposed by both Habili et al. (9) and Jordan (11). The purpose of this study was to provide quantitative information concerning the temporal and spatial spread of GLRaV-3 in grapevines in South Australia and New Zealand.

\section{MATERIALS AND METHODS}

Source of plant material. Thirteen $\mathrm{Pi}$ not Noir (Vitis vinifera L.) clones replicated eight times (104 plants) were planted at the Nuriootpa Research and Advisory Centre, Nuriootpa, South Australia, in 1986. The 13 clones and their countries of origin were described previously by Habili et al. (9). The entire experiment was surrounded by symptomless, buffer grape vines. Following transplanting, all vines were tested for the presence of GLRaV-3, and three clones ( 24 of the 104 vines) were found to be infected as determined by a biological (graft inoculation) assay (9). Infected vines were not identified prior to transplanting; thus, infected grapevines were randomly positioned within a plot four rows wide by 26 transplants long (9).

Serological assay. Leaf samples were collected in mid to late March of each year and tested by using a double antibody sandwich enzyme-linked immunosorbent assay (DAS-ELISA) (6,9). A monoclonal antibody and its conjugate specific for GLRaV-3 were obtained from Bioreba AG, Basel, Switzerland, and each vine was tested at least twice by extracting petioles and midribs of mature leaves. Extracts were prepared by crushing $0.15 \mathrm{~g}$ of midrib tissues from mature leaves in $0.5 \mathrm{ml}$ of extraction buffer (9) within a sealed plastic bag. Absorbance was recorded at $405 \mathrm{~nm}$ using an automatic microplate reader (BioRad Laboratories, Richmond, CA). Samples with absorbance readings exceeding three times that of the healthy control were considered positive for the presence of GLRaV-3.

New Zealand GLRaV-3 epidemic. The temporal and spatial spread of a GLRaV-3 epidemic in Cabernet Sauvignon grapevines in New Zealand during the years 1988 to 1992 (11) were also analyzed to allow the comparison of this epidemic to the spread of GLRaV-3 in South Australia. Although disease progress with respect to time and a spatial pattern map of GLRaV-3-infected grape vines for this epidemic have been published (11), no statistical analyses were performed to quantify temporal or spatial spread. Initial infection in this vineyard (eight rows by 11 plants per row) was traced to two GLRaV-3-infected clones (eight vines), and these eight vines were planted in a random distribution in 1985 with GLRaV-3 spread being observed and 

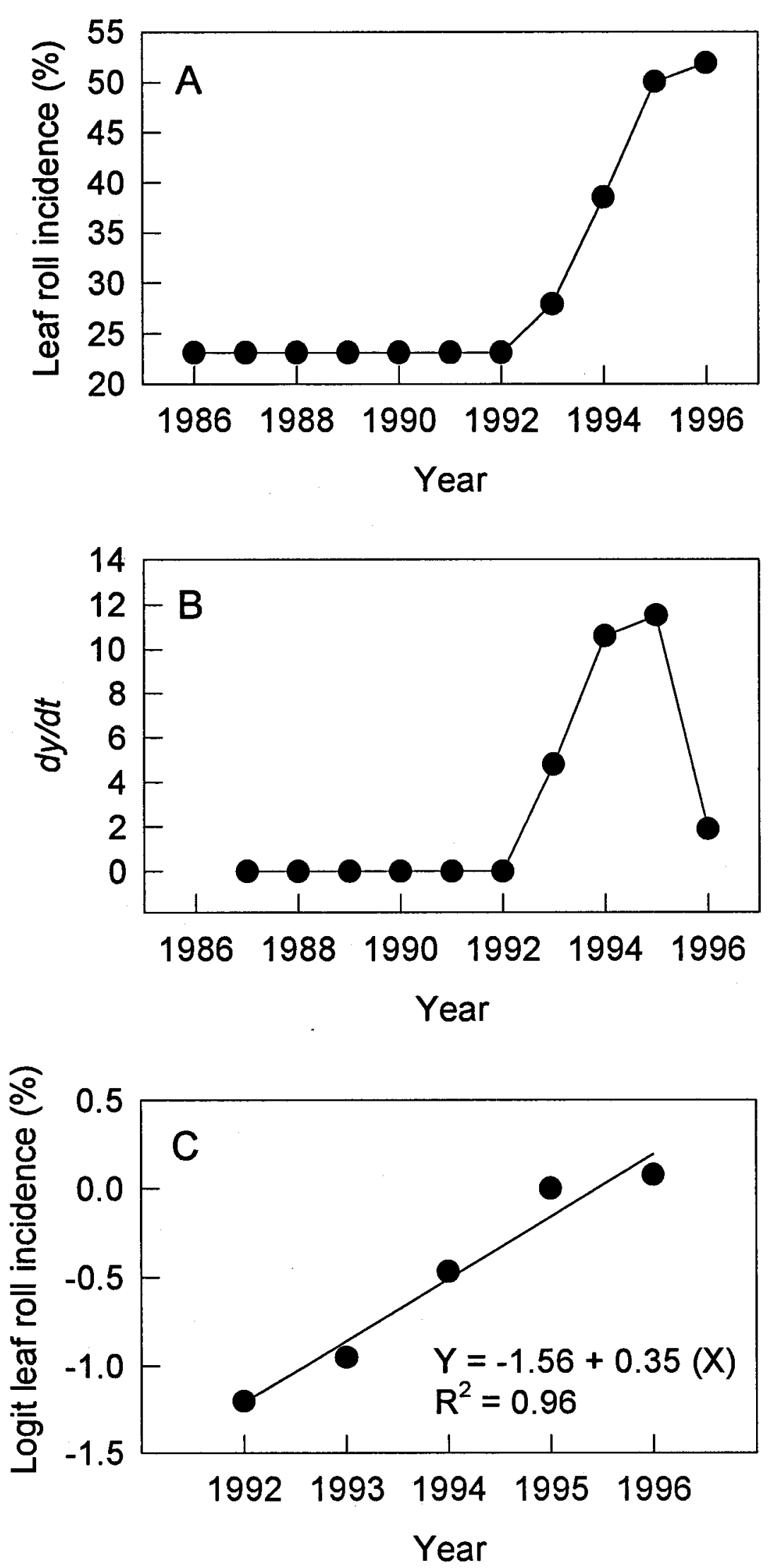

Fig. 1. Disease progress of grapevine leafroll disease. (A) Progress of grapevine leafroll disease (GLD) caused by grapevine leafroll-associated virus 3 (GLRaV-3) in South Australia during 1993 to 1996. Initial GLD incidence was $23.1 \%$ at the time of planting in 1986 and no spread was detected until 1993; (B) Graph of the change in rate $(d y / d t)$ of GLRaV-3 spread with respect to time; (C) Logit GLD incidence versus time. The slope of the regression line ( 0.35 logit/year) is the apparent rate of GLD spread. recorded from 1988 (9.1\% incidence) to 1992 (93.1\% incidence).

Statistical analyses. Disease progress curves, rate curves (the change in disease incidence with the change in time versus time, $d y / d t$ versus $t$ ), and regression analyses were collectively used to determine the most appropriate model for quantifying temporal disease spread for both epidemics. Incidence of GLRaV-3-infected Pinot Noir grapevines grown in South Australia and the increase in GLRaV-3 incidence in Cabernet Sauvignon grapes grown in New Zealand were plotted versus year of assessment (time) to obtain disease progress curves. In addition, changes in incidence with the change in time $(d y / d t)$ versus time were also plotted. Disease progress curves were fitted to the linear (nontransformed $y$ ), monomolecular, exponential, logistic, and Gompertz growth models to determine which model would best linearize the relationship between transformed GLRaV-3 incidence $(y)$ and time (15). Model selection for both epidemics was based on a significant $F$ statistic $(P \leq 0.05)$, which determines if there is a linear relationship between transformed $(y)$ and time; the coefficient of determination $\left(R^{2}\right)$, which provides a measure of the amount of the variation in transformed $(y)$ explained by time; the standard error of the estimate for $y\left(\mathrm{SEE}_{\mathrm{Y}}\right)$, which provides a measure of the variation about a predicted value of $y$; and by visually inspecting the plot of the residuals (predicted $y$ minus actual $y$ ) versus time to discern if an unacceptable pattern was present (16). Once a model was chosen, the slope of the regression line relating transformed $(y)$ to time was taken as a measure of the temporal rate of GLRaV-3 spread with respect to time $(14,16)$.

The spatial position (row, column) of each GLRaV-3-infected plant was recorded for each year of assessment. Ordinary runs analysis (3) for combined rows was used to determine randomness (null hypothesis) or degree of clustering (alternative hypothesis) of the spatial pattern of GLRaV-3-infected plants for each year of assessment. A run is described as the succession of one or more diseased or healthy plants (3). The expected number of runs $(E)$ under the null hypothesis of randomness is given by

$$
E=1+\frac{2 m(N-m)}{N}
$$

where $m$ is the number of infected plants and $N$ is the total number of plants per row or combined rows (3).

The observed number of runs is less than the expected number of runs $(E)$ if there is clustering of GLRaV-3-infected plants. A normal $Z$ test is used to determine clustering, with a value of $Z$ less than -1.64 indicating clustering $(P \leq 0.05)(3)$.

\section{RESULTS AND DISCUSSION}

Although GLD incidence in Pinot Noir grapevine clones was $23.1 \%$ at the time of 
planting in 1986, no spread was detected until 1993, at which point disease progress increased rapidly in succeeding years (Fig. 1A). The rate plot ( $d y / d t$ versus $t$ ) for this epidemic (Fig. 1B) indicated that the logistic or Gompertz transformations would probably best describe GLRaV-3 disease progress with respect to time (3), and therefore the monomolecular and exponential population growth models were excluded from consideration as a means to linearize disease progress for this epidemic (15). Because the logistic $\left(F=73.3, R^{2}=\right.$ $96.2 \%, \mathrm{SEE}_{\mathrm{Y}}=0.127$, residual plot was acceptable) and the Gompertz $(F=77.6$, $R^{2}=96.3 \%, \mathrm{SEE}_{\mathrm{Y}}=0.080$, residual plot was acceptable) models both adequately described GLRaV-3 disease progress, this would suggest that GLRaV-3-infected plants are infectious and contributing to new infections; e.g., the absolute rate $(d y / d t)$ increases as GLRaV-3 incidence increases. If these models are interpreted biologically, the absolute rate first increases as $(y)$ increases, then $d y / d t$ will begin to decrease (as happened in 1996) as the percentage of healthy plants $(1-y)$ decreases. The inflection points of these two models, however, are quite different $(y$ $=0.5$ for the logistic model and $y=0.37$ for the Gompertz model) $(3,15)$. Because the inflection point for this epidemic was closer to 0.50 than to 0.37 , we chose the logistic model to linearize the relationship between GLRaV-3 disease increase and time. Moreover, the logistic model is a simpler biological model with fewer assumptions than the Gompertz model $(3,15)$. The slope of the logistic regression line was $0.35 \pm 0.040$ logit/year and is the estimated rate of GLRaV-3 infection with respect to time (Fig. 1C). Although ordinary least squares regression analysis assumes a normal distribution to estimate rate parameters, normality may be a reasonable assumption when $n$ (sample units $=$ vines $)$ is large ( $n=104$ in this study) and disease incidence is not too small (13).

The GLRaV-3 epidemic in New Zealand is currently the only other known data set to report the temporal spread of GLRaV-3 in grapevines (11). Although no statistical analyses were performed in the original report (11), GLRaV-3 incidence was reported to nearly double each year, with the absolute rate of disease development being slower in years 3 to 5 relative to the abso- lute rate in years 1 to 3 , which resulted in a sigmoidal disease progress curve. Using the same selection criteria as for the GLRaV-3 epidemic in South Australia, the logistic model was again chosen to describe disease progress at the GLRaV-3 epidemic reported in New Zealand $\left(R^{2}=\right.$ $96.0 \%)$. Therefore, the logistic model was also used for this epidemic to estimate the rate parameter in order to compare infection rates of both epidemics using the same model. The rate of infection for the New Zealand epidemic was 1.19 logits/year, which was approximately three times faster than the infection rate in Pinot Noir grapevines in Australia (0.35 year). At this time, it is not known if the higher rate of GLRaV-3 infection in New Zealand was due to differences in grapevine cultivars, more efficient or more abundant biotic vector populations, or differences in the aggressiveness of GLRaV-3 strains. In a related pathosystem, Tanne et al. (19) reported the temporal spread of corky bark disease in grapevines (caused by the closely related closterovirus, GLRaV-2) was also best described by the logistic model, which may be taken as evidence that plant-to-plant spread also occurs in this pathosystem. The rate of disease spread in this pathosystem was somewhat slower $(r=0.25 \pm 0.024 /$ year $)$ than the logistic infection rates for GLRaV-3 reported in this paper.

The spatial pattern of infected plants at the time of planting in 1986 in South Australia, as determined by ordinary runs analysis (3), was random (Table 1). In the first year of observed spread (1993), the spatial pattern remained random; however, from 1994 to 1996 the spatial distribution was found to be clustered. This was because observed spread was largely from infected to adjacent plants within rows. Ordinary runs analyses conducted across rows (data not shown) indicated that the null hypothesis for randomness across rows could not be rejected $(P>0.05)$; thus, spread was largely limited to within rows. Jordan (11) also observed that GLRaV-3 spread in New Zealand was "often spread only (from infected) to adjacent vines". Although no statistical analyses were performed on this data in the New Zealand report, ordinary runs analyses that we performed on the data indicated a change from a random to a clustered spatial pattern of

Table 1. Ordinary runs analysis for the spatial distribution of grapevine leafroll-associated virus 3 (GLRaV-3)-infected grapevines during the years of temporal spread 1993 to 1996

\begin{tabular}{lcccc}
\hline \multirow{2}{*}{$\begin{array}{l}\text { Year of } \\
\text { assessment }\end{array}$} & $\begin{array}{c}\text { Total } \\
\text { infected }^{\mathbf{a}}\end{array}$ & \multicolumn{2}{c}{ Number of runs } & \multirow{2}{*}{$\begin{array}{c}\text { Standardized } \\
\text { z-score }\end{array}$} \\
& 24 & Expected & Observed & \\
\hline 1986 & 29 & 41 & 44 & 0.9968 \\
1993 & 41 & 46 & 42 & -0.8171 \\
1994 & 52 & 54 & 39 & $-2.9253 * \mathrm{~b}$ \\
1995 & 54 & 56 & 35 & $-4.0400 *$ \\
1996 & 56 & 35 & $-4.0309 *$ \\
\hline
\end{tabular}

a Number of GLRaV-3-infected Pinot Noir grapevines out of a total of 104 (combined rows).

$\mathrm{b} *$ indicates the null hypothesis for randomness was rejected $(P \leq 0.05)$.

infected grapevines beginning in 1990 (5 years after planting). The pattern of spread in both the New Zealand and the South Australian epidemics is strong evidence to support the hypotheses that plant-to-plant spread is occurring and that a biotic vector with a steep dispersal gradient from each point source is involved. To date, no vector has been found in South Australia; however, several biotic vectors for GLRaV-3 have been reported in other countries $(1,8,17)$.

There is insufficient information to attempt to explain why GLD incidence did not increase until 1993 in South Australia, which was 8 years after planting. Although at least one known GLRaV-3 vector, Pseudococcus longispinus Targioni-Tozzetti (20), has been present in Australia for decades, there was no record of GLRaV-3 spread in Australian vineyards until 1993. Since 1993, GLRaV-3 spread has been observed in additional vineyards in South Australia and Victoria, Australia. Because GLRaV-3 spread has been observed only recently in Australia, additional research is needed to determine if a mealybug or other new vectors have entered the country, or if a new strain of GLRaV-3 is involved.

\section{LITERATURE CITED}

1. Belli, G., Fortusini, A., Casati, P., Belli, L., Bianco, P. A., and Prati, S. 1994. Transmission of grapevine leafroll associated closterovirus by the scale insect Pulvinaria vitis L. Riv. Patol. Veg. 4:105-108.

2. Boscia, D., Greif, C., Gugerli, P., Martelli, G. P., Walter, B., and Gonsalves, D. 1995. The nomenclature of grapevine leafroll-associated putative closteroviruses. Vitis 34:171-175.

3. Campbell, C. L., and Madden, L. V. 1990. Introduction to Plant Disease Epidemiology. John Wiley \& Sons, New York.

4. Candresse, T., and Martelli, G. P. 1995. Genus Closterovirus. Pages 461-464 in: Virus Taxonomy. VIth Rep. Int. Committee on Taxonomy of Viruses. F. A. Murphy, C. M. Fauquet, D. H. L. Bishop, S. A. Ghabrial, A. W. Jarvis, G. P. Martelli, M. A. Mayo, and M. D. Summers, eds. Springer-Verlag, Vienna.

5. Choueiri, E., Boscia, D., Digiaro, M., Castellano, M. A., and Martelli, G. P. 1996. Some properties of a hitherto undescribed filamentous virus of the grapevine. Vitis 35:91-93.

6. Clark, M. F., and Adams, A. N. 1977. Characteristics of the microplate method of enzyme-linked immunosorbent assay for the detection of plant viruses. J. Gen. Virol. 34:475-483.

7. Engelbrecht, D. J., and Kasdorf, G. G. F. 1990. Field spread of corky bark, fleck, leafroll and Shiraz decline diseases and associated viruses in South African grapevines. Phytophylactica 22:347-354.

8. Golino, D. A., Sim, S. T., Gill, R. S., and Rowhani, A. 1994. Evidence that California mealybug can transmit grapevine leafroll-associated viruses. Abstr. Meet. Am. Soc. Enol. Vitic., Anaheim, CA.

9. Habili, N., Fazeli, C. F., Ewart, A., Hamilton, R., Cirami, R., Saldarelli, P., Minafra, A., and Rezaian, M. A. 1995. Natural spread and molecular analysis of grapevine leafroll-associated virus 3 in Australia. Phytopathology 85:1418-1422.

10. Hewitt, W. B., Goheen, A. C., Raski, D. J., and Gooding, G. V. 1962. Studies on virus diseases of grapevines in California. Vitis 3:57-83. 
11. Jordan, D. 1993. Leafroll spread in New Zealand vineyards. Aust. N.Z. Wine Ind. J. 8:322-324.

12. Krake, L. R. 1993. Characterization of grapevine leafroll disease by symptomatology. Aust. N.Z. Wine Ind. J. 8:40-44.

13. Madden, L. V., and Hughes, G. 1995. Plant disease incidence: Distributions, heterogeneity, and temporal analysis. Annu. Rev. Phytopathol. 33:529-564.

14. Nutter, F. W., Jr., Hill, J. H., and Schultz, P. M. 1994. Modeling within field spread of soybean mosaic virus with strain-specific monoclonal antibodies. (Abstr.) Phytopathology $84: 1159$.

15. Nutter, F. W., Jr., and Parker, J. K. 1997.
Fitting disease progress curves using EPIMODEL. Pages 24-28 in: Exercises in Plant Disease Epidemiology. L. Francl and D. Neher, eds. American Phytopathological Society, St. Paul, MN.

16. Padgett, G. B., Nutter, F. W., Jr., Kuhn, C. W., and All, J. N. 1990. Quantification of disease resistance that reduces the rate of tobacco etch virus epidemics in bell pepper. Phytopathology 80:451-455.

17. Rosciglione, B., and Gugerli, P. 1989. Transmission of grapevine leafroll disease and an associated closterovirus to healthy grapevine by the mealybug Planococcus ficus Signoret. Pages 67-69 in: Proc. Meet. ICVG, 9th. Kiryat Anarim, Israel.
18. Tanne, E., Ben-Dov, Y., and Raccah, B. 1989. Transmission of closterolike particles associated with grapevine leafroll by mealybugs (Pseudoccidae) in Israel. Pages 71-73 in: Proc. Meet. ICVG, 9th. Kiryat Anarim, Israel.

19. Tanne, E., Marcus, R., Dubitzky, E., and Raccah, B. 1996. Analysis of progress and spatial pattern of corky bark in grapes. Plant Dis. 80:34-38.

20. Williams, D. J. 1985. Australian mealybugs. British Museum (Natural History) Publication, London.

21. Woodham, R. C., Antcliff, A. J., Krake, L. R., and Taylor, R. H. 1984. Yield differences between Sultana clones related to virus status and genetic factors. Vitis 23:73-83. 